IRA-International Journal of Management \&

Social Sciences

ISSN 2455-2267; Vol.10, Issue 02 (February 2018)

Pg. no. 63-73.

Institute of Research Advances

http://research-advances.org/index.php/RAJMSS

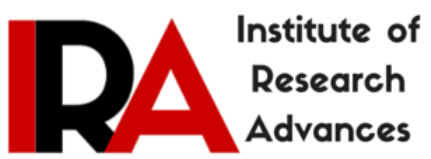

\title{
Business Information Sciences emphasizing Digital Marketing as an emerging field of Business \& IT: A Study of Indian Private Universities
}

P. K. Paul ${ }^{1 \#}$, A. Bhuimali ${ }^{2}$, P.S. Aithal ${ }^{3}$

${ }^{1}$ Raiganj University (RGU), West Bengal, India

${ }^{2}$ Vice Chancellor, Raiganj University, West Bengal, India

${ }^{3}$ Vice Chancellor, Srinivas University, Karnataka, India

\# corresponding author.

Type of Review: Peer Reviewed.

DOI: http://dx.doi.org/10.21013/jmss.v10.n2.p1

How to cite this paper:

Paul, P.K., Bhuimali, A., Aithal, P.S. (2018). Business Information Sciences emphasizing Digital Marketing as an emerging field of Business \& IT: A Study of Indian Private Universities. IRAInternational Journal of Management \& Social Sciences (ISSN 2455-2267), 10(2), 63-73. doi:http://dx.doi.org/10.21013/jmss.v10.n2.p1

(C) Institute of Research Advances.

\section{(cc) $\mathrm{BY}-\mathrm{NC}$}

This work is licensed under a Creative Commons Attribution-Non Commercial 4.0 International License subject to proper citation to the publication source of the work.

Disclaimer: The scholarly papers as reviewed and published by the Institute of Research Advances (IRA) are the views and opinions of their respective authors and are not the views or opinions of the IRA. The IRA disclaims of any harm or loss caused due to the published content to any party.

Institute of Research Advances is an institutional publisher member of Publishers Inter Linking Association Inc. (PILA-CrossRef), USA. The institute is an institutional signatory to the Budapest Open Access Initiative, Hungary advocating the open access of scientific and scholarly knowledge. The Institute is a registered content provider under Open Access Initiative Protocol for Metadata Harvesting (OAI-PMH).

The journal is indexed \& included in WorldCat Discovery Service (USA), CrossRef Metadata Search (USA), WorldCat (USA), OCLC (USA), Open J-Gate (India), EZB (Germany) Scilit (Switzerland), Airiti (China), Bielefeld Academic Search Engine (BASE) of Bielefeld University, Germany, PKP Index of Simon Fraser University, Canada. 


\begin{abstract}
Informatics is an interdisciplinary area and domain responsible for information related affairs with the help of technologies; particularly Information Technologies and Computing. Business Informatics initially was termed and popularized as a practicing area for the business affairs. Gradually the concept developed as a branch of study. The concept of Business Informatics was first introduced in Germany. Business Informatics is a combination of Business Studies/Management with Information Science/Informatics. There are many related fields of Business Informatics viz. Information Systems, IT Management, Organizational Informatics etc. As the terms Informatics and Information Science are synonyms in many contexts, business informatics can also be called with nomenclature as Business Information Science. The branch of Information Science is a field of fields and thus it is also currently called Information Sciences (the plural). Hence the branch of Business Information Science may also be called as a broad one with the nomenclature 'Business Information Sciences'. The nomenclature Business Information Science with a degree in India is not yet started though as far as knowledge mapping is concerned the field may be designated with the nomenclature associated with Business and IT. In this respect, the subjects and program like Information Systems, IT Project, Information Technology Management may be considered as important and vital for the field as 'Business Information Sciences'. India is rapidly moving in higher education segment and thus many new branches have been developed and started in recent past and among these, Digital Marketing is an important one. In this paper an investigation and observation have been undertaken to learn about the Digital Marketing as a branch of Interdisciplinary Sciences in Private Universities in India.
\end{abstract}

Keywords: Informatics, Information Science, Business Information Science, IT Management, India, Development, Research, Interdisciplinary Science, Academics.

\title{
Introduction
}

Information Science is not the only deal with the information activities with manual knowledge organization tools but also IT and computational affairs. Information Science is similar to Informatics which has different foci and also domain centric concentration. Generally Information Science is a broad branch of study consisting with the Information Technology (i.e. mainly Networking Technology, Database Technology, Multimedia Technology, Web Technology, Communication Technology, Software Technology etc), Information Studies (i.e. mainly Information Management, Knowledge Organization etc) and Management and Social Sciences. Hence it is a broad and interdisciplinary field of fields with a due concentration on information and technologies. The field is also domain centric and results in many fields of study viz. Health Information Science, Geo Information Science, Chemo Informatics etc [1], [2], [9].

Similar to these, integration of Business Studies/ Management with Informatics/Information Science has resulted in the Business Information solution and technological solution and the branch called Business Information Science has been created. Business Informatics is more popular nomenclature which is mainly restricted towards the following-

- Business fundamentals and Organization Information,

- Infrastructure building,

- Management Information Systems designing and development,

- Enterprise Resource Planning,

- Decision Support Systems etc

It is worthy to note that the field Business Informatics is helpful in Business Information and Documentation solution with the help of manual tools and computerization systems. The present study has been carried to find out this field in Indian Private Universities [3], [4], [10]. And as a case study all the subjects and programs leading to Bachelors and Masters degrees in the circle of Business and Information Sciences have been mapped (except MBA in IT). It is important to note that some of the emerging areas viz. Digital Marketing, Digital Business, E-Commerce etc are also been studied and considered within the branch of Business Information Sciences. 


\section{Objective and Agenda}

The present paper is fully conceptual in nature and deals with various aim and objective; among these few important are-

- To learn about the basic of Information Science and its domain centric concentration and various nomenclature available.

- To dig out the nature of Business Information Science and allied fields including its components and areas.

- To learn about the academic programs available worldwide in the field of Business Information Science.

- To know about the possible areas to be within the field of Business Information Science with reference to the academic programs available in the private universities.

- To know about the Higher Education Systems in India with reference to the private universities in India.

- To learn about the branches of E-Commerce, Digital Marketing as an important and growing field within Business Information Sciences available in the Private Universities.

\section{Methods Adopted}

The present work is conceptual in nature and thus for carrying the work, several methods have been adopted. Firstly, the method of Literature review is adopted and here books and journals review initially completed for gaining knowledge in different fields and areas viz. basics of Information Sciences; its nature and domain, the field of Business Informatics and basics of the Digital Marketing, E-Commerce etc. Moreover, web review has been undertaken to learn about the Private Universities available in India and for this, core website was considered as UGC (i.e.) ; though apart from these the URL of MHRD, AICTE considered for collecting information on different areas and topic. For the completion of the work and scope of the Business Information Sciences the availability of Bachelors and Masters programs considered and selected to analyze the field. Hence except the IT Management and Information Systems all the areas were studied and included irrespective of award (i.e. Bachelors or Masters; for example MSc-IT also selected as the program offered as MSc-IT (E-Commerce).

\section{Business Information Sciences: An Introduction}

Information Science is the largest and important interdisciplinary field of fields these days and it is still growing [5], [7], [11]. Initially, it was considered as only a field of information and related affairs but gradually the integration of tools, techniques, and technologies changed the entire arena of Information Science. It is worthy to note that Information Science is popular with few other nomenclature and fields (with a very basic difference); among these few important are include-

- Informatics

- Information Systems

- Information Management

- Knowledge Systems and Management

- Information Science and Technology

- Information Science and Computing

- Computer and Information Science

- Information and Computer Science

- Information Science and Systems etc.

Though apart from these, the field 'Information Studies' also considered as important though its concentration on technologies is limited than others mentioned above [6], [10], [14-15]. It is important to note that in general, the combination of the above branches also called as 'Information Science' / 'Information Sciences'. Even the departments offer many such programs also called as Department of 'Information Science/s'.

Significantly the branch is later on concentrated with other domains and created many new nomenclatures viz. Geo Information Science, Health Information Science, Environmental Information Science, Library Information Science etc. Similar to these, Business Information Science has also been developed internationally as a branch of study. Though similar to other cases the term also popularized as Business Informatics. Though, the integration of Business systems and information systems, IT Management, IT Policies, IT Governances, IT applications in the organizations 
and institutions etc are also called as Business Information Sciences. Hence Business Information Sciences may be considered as a broad branch of study and will capture not only Business Information Science subject (refer Fig: 1).

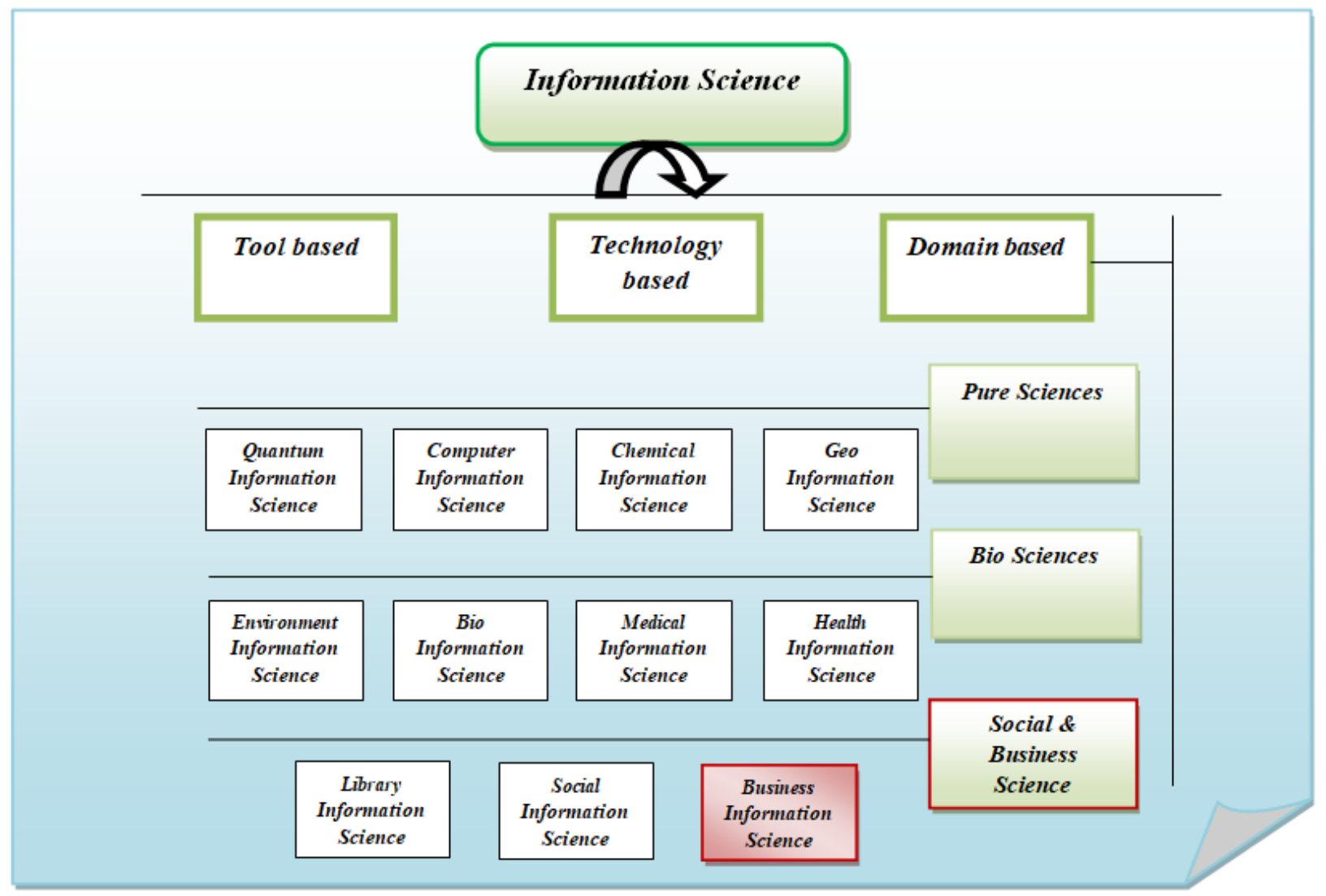

Fig: 1- Domain based Information Science with reference to Business Information Science (P.K.Paul, 2016)

\section{Digital Marketing an Emerging Branch}

Digital Marketing is an important concept these days and it may also be considered as an emerging area within Business Information Sciences [9], [18]. In general, this is a kind of marketing in which products and services are offered with the help of Information Technologies or simply Digital Technologies. It is useful to Internet Technology and Mobile phone in current time. The concept is very much similar with E-Commerce and E-Business but it is closely associated with the following-

- Search Engine Optimization

- Search Engine Marketing

- Content Marketing

- $\quad$ E-Mail Marketing

- Social Media Marketing \& Optimization etc

The concept of Digital Marketing in many ways termed as Digital Business as well. The concept of Digital Marketing was popularized during 1990s and 2000s. The trends of such type of businesses have been increased in recent past. Apart from the methods adopted above the Digital Marketing also uses the strategies viz. content automation, data driven marketing, content automation, and so on. Hence internationally many universities have started several Digital Marketing Programs. Few programs in this regard with MSc Digital Marketing have been depicted in Table: 1. 
Table: 1-Digital Marketing in International Universities- A Snapshot

\begin{tabular}{|c|c|c|}
\hline \multicolumn{2}{|c|}{ Universities } & Programs \\
\hline 1 & INSEEC U Business Schools, Geneva & Masters in Digital Marketing \& Social \\
& & Media \\
\hline 2 & Robert Gorden University, UK & MSc Digital Marketing \\
\hline 3 & IESEG School of Management, France & MSc Digital Marketing \& CRM \\
\hline 4 & SKEMA Business School & MSc Digital Marketing \\
\hline 5 & University of Brighton, Switzerland & MSc Digital Marketing \\
\hline 6 & University of Salford Manchester, Salford, UK & MSc Digital Marketing \\
\hline 7 & Manchester Metropolitan University, UK & MSc Digital Marketing Communications \\
\hline 8 & The University of Hong Kong, China & MSc Digital Marketing \\
\hline 9 & Nottingham Trent University, UK & MSc Strategic Digital Marketing \\
\hline 10 & University of South Wales, UK &
\end{tabular}

Digital Business is another important area within Management Sciences concentrated within Information Technology. It is broader than Digital Marketing and combines with other areas of Business and Management. Like Digital Marketing, the field Digital Business also started as an academic program in many international universities and it may also consider as a branch of Business Information Sciences. Table: 2 depicts few international universities in this regard.

Table: 2-Digital Business MSc in International Universities- A Look

\begin{tabular}{|c|c|c|}
\hline \multicolumn{3}{|c|}{ Digital Business Masters/ MSc Programs } \\
\hline & Universities & Programs \\
\hline 1 & SKEMA Business Schools & MSc Digital Business \\
\hline 2 & Grenoble Ecole de Management & MSc Digital Business \& Entrepreneurship \\
\hline 3 & University of Southampton & MSc Digital Business \\
\hline 4 & Irish Management Institute & MSc Digital Business \\
\hline 5 & EDHEC Business School & \\
\hline
\end{tabular}

\section{Digital Marketing Domain in Indian Private Universities}

India is one of the largest democracies in the world and it is also home to large number of higher educational institutes (HEIs) in the world [6], [12], [14]. Indian Higher Education System consists of Universities, Colleges, Research Centers, Institute of National Importance, Autonomous Institutes and so on. In India universities are divided into four (4) main categories viz. Central University, State University, Private University, and Deemed to be University. As a whole, as on October, 2017 during the study India holds 279 Universities with Private Tag in its bag (please refer Table: 3 for more clarification).

Table: 3-Distribution of Private Universities in India

\begin{tabular}{|c|l|c|}
\hline Serial No. & \multicolumn{1}{|c|}{ States } & No. of Universities \\
\hline 1 & Arunachal Pradesh & 7 \\
\hline 2 & Assam & 5 \\
\hline 3 & Bihar & 2 \\
\hline 4 & Chhattisgarh & 9 \\
\hline 5 & Gujarat & 20 \\
\hline 6 & Haryana \\
\hline
\end{tabular}




\begin{tabular}{|c|l|c|}
\hline 7 & Himachal Pradesh & 17 \\
\hline 8 & Jharkhand & 7 \\
\hline 9 & Karnataka & 14 \\
\hline 10 & Meghalaya & 8 \\
\hline 11 & Mizoram & 1 \\
\hline 12 & Madhya Pradesh & 24 \\
\hline 13 & Maharashtra & 1 \\
\hline 14 & Manipur & 3 \\
\hline 15 & Nagaland & 4 \\
\hline 16 & Odisha & 15 \\
\hline 17 & Punjab & 46 \\
\hline 18 & Rajasthan & 5 \\
\hline 19 & Sikkim & 1 \\
\hline 20 & Tripura & 29 \\
\hline 21 & Uttar Pradesh & 13 \\
\hline 22 & Uttrakhand & 279 \\
\hline 23 & West Bengal & \\
\hline \multicolumn{2}{r}{ Grand Total } & \\
\hline & &
\end{tabular}

As far as this study is concerned it has been noted that within the segment of Business Information Sciences the areas of Digital Marketing, E-Commerce, E Business (excluding IT Management-MBA/MSc, Information Systems$M B A / M S c$ ) are considered. And in this respect all such degrees viz. MSc, MBA etc have been mapped even they are within any degrees or specializations (viz. MSc-IT- E-Commerce). According to the study it has been noted that among the 279 universities 15 are offering Business Information Science programs in respect of Masters Degrees [13], [17], [19]. And it is worthy to note that even in among these degrees few important are-

- MBA-Digital Marketing

- $\quad$ MBA-E-Commerce

- MBA-Digital Marketing \& E-Commerce etc

Importantly apart from MBA, few have started with other tags like MCom and MSc. For example, Kalinga University, CG offers MCom (E-Commerce) while GLS University offers MSc-IT (E-Commerce) specializations (Table: 4).

Table: 4-Private Universities in India offering Programs on Business Information Sciences

\begin{tabular}{|c|c|c|}
\hline \multicolumn{3}{|c|}{ Business Information Sciences as a Digital Marketing Programs (Masters) } \\
\hline & Universities & Programs \\
\hline 1 & Assam Down Town University & MBA (Digital Marketing) with TimesPrO \\
\hline 2 & Kalinga University & $\begin{array}{c}\text { MCom (E-Commerce) } \\
\text { MBA (Digital Marketing) } \\
\text { MBA (E-Commerce) }\end{array}$ \\
\hline 3 & GLS University & MSc-IT ( E-Commerce) \\
\hline 4 & Shree Guru Gobind Singh Tricentenary & MBA (Digital Marketing) \\
\hline 5 & Aniversity & MBA (Digital Marketing \& E-Commerce) \\
\hline 6 & Centurion University of Technology and & MBA (Digital Marketing \& E-Commerce) \\
\hline 7 & Lovely Professional University & MBA (E-Commerce) \\
\hline 8 & Rayat Bahra University & MBA (Digital Marketing) \\
\hline
\end{tabular}




\begin{tabular}{|c|c|c|}
\hline 9 & RIMT University & MBA (Digital Marketing) \\
\hline 10 & NIIT University & $\begin{array}{c}\text { MBA (Digital Marketing) } \\
\text { MBA( E Commerce) }\end{array}$ \\
\hline 11 & ICFAI University, Tripura & MBA (Digital Marketing) \\
\hline 12 & Teerthanker Mahaveer University, UP & MBA (Digital Marketing) \\
\hline 13 & Uttaranchal University, Dehradun & MBA (Digital Marketing \& E-Commerce) \\
\hline 14 & Adamas University, Kolkata & MBA (Digital Marketing) \\
\hline 15 & University of Engineering and Management & MBA (Digital Marketing) \\
\hline \multicolumn{2}{r|}{ No. of Total Universities 15 } & Total PG Programs 18 \\
& &
\end{tabular}

It is worthy to note that even few universities have started more than one programs at Masters level such as NIIT University, Rajasthan, Kalinga University, CG. As a whole among these fifteen (15) universities total 18 programs are offered. It has been studied that among these eighteen (18) programs, 13 (thirteen) programs are directly from the nomenclature Digital Marketing while remaining of the programs are from allied areas within Business Information Sciences (please refer Fig: 2).

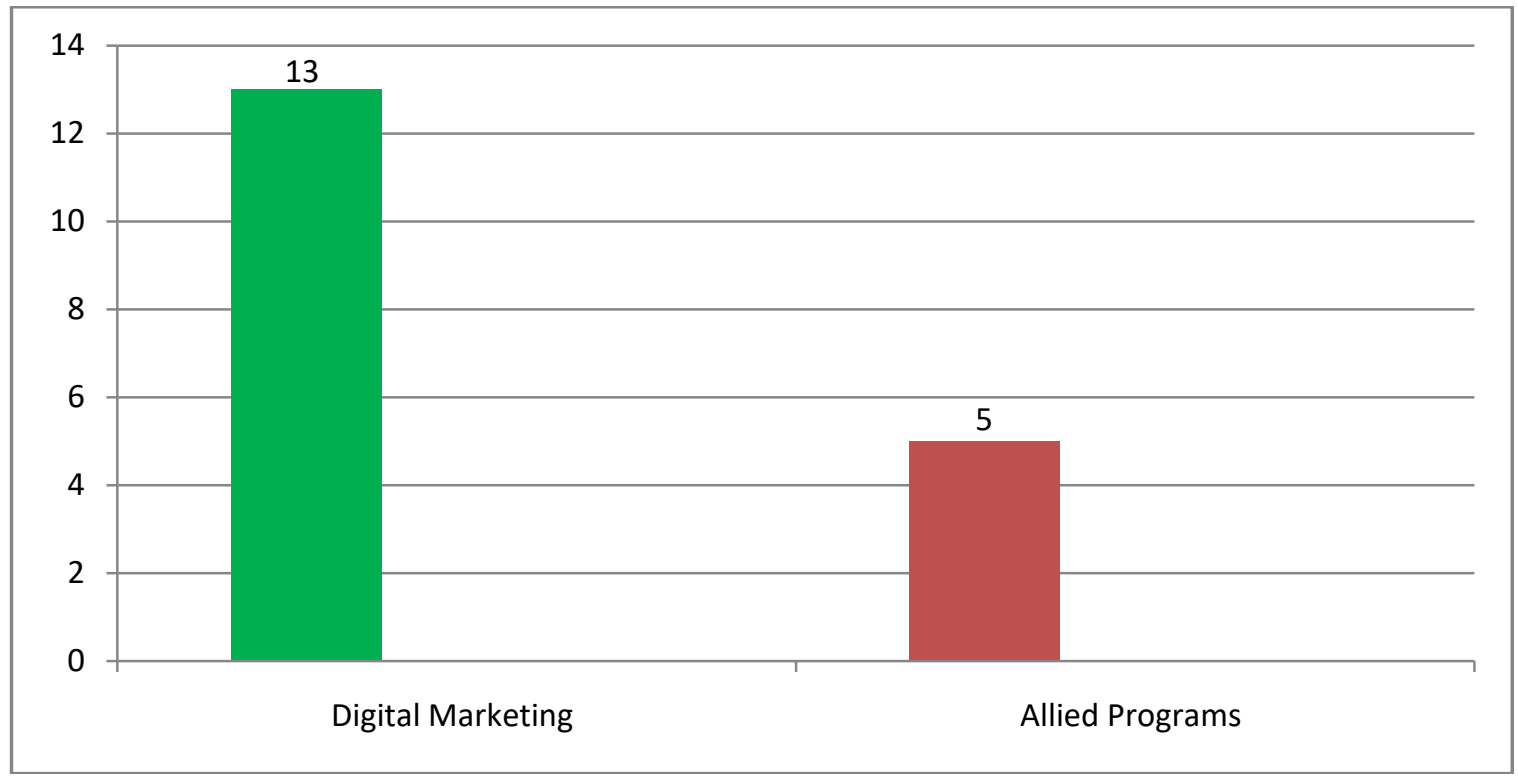

Fig: 2 -Distribution of Business Information Sciences at Private Universities (Digital Marketing Vs. Allied Programs) in India

The Universities which are offered the Digital Marketing as Masters programs have been listed in Table: 5. It is worthy to note that few universities offered merged program as Digital Marketing with E-Commerce. In respect of job and placement, the nomenclature may be suitable.

Table: 5-Private Universities in India offering Programs on only Digital Marketing within the area of Business Information Sciences

$$
\text { Digital Marketing Masters Programs }
$$

\begin{tabular}{|c|c|c|}
\hline & Universities & Programs \\
\hline 1 & Assam Down Town University & MBA (Digital Marketing) with TimesPrO \\
\hline 2 & Kalinga University & MBA (Digital Marketing) \\
\hline
\end{tabular}




\begin{tabular}{|c|c|c|}
\hline 3 & $\begin{array}{c}\text { Shree Guru Gobind Singh Tricentenary } \\
\text { University }\end{array}$ & MBA (Digital Marketing) \\
\hline 4 & Ajeenkya D.Y. Patil University & MBA (Digital Marketing \& E-Commerce) \\
\hline 5 & $\begin{array}{c}\text { Centurion University of Technology and } \\
\text { Management }\end{array}$ & MBA (Digital Marketing \& E-Commerce) \\
\hline 6 & Rayat Bahra University & MBA (Digital Marketing) \\
\hline 7 & RIMT University & MBA (Digital Marketing) \\
\hline 8 & NIIT University & MBA (Digital Marketing) \\
\hline 9 & ICFAI University, Tripura & MBA (Digital Marketing) \\
\hline 10 & Teerthanker Mahaveer University, UP & MBA (Digital Marketing \& E-Commerce) \\
\hline 11 & Uttaranchal University, Dehradun & MBA (Digital Marketing) \\
\hline 12 & Adamas University, Kolkata & MBA (Digital Marketing) \\
\hline 13 & University of Engineering and Management & Total PG Programs 13 \\
\hline \multicolumn{2}{|c}{ No. of Total Universities 13 }
\end{tabular}

Most of the Digital Marketing programs basically deal with equal aim and agenda; while few programs also deal business and management curricula. In general, the common curricula include-

- Understand the various nuances of digital marketing which includes SEO, SMM, e-mail marketing, PPC, etc.

- Create the right content and campaigns for different target groups.

- Generating knowledge of the current scenario, issues, and opportunities in e-shopping, e-distribution, ecollaboration, e-SCM etc.

- To learn about the issues and skills in respect of e-business, and more deeply security, authentication, privacy, and intellectual property regulations.

Table: 6-Sample MBA-Digital Marketing curricula

\begin{tabular}{|c|c|}
\hline \multicolumn{2}{|c|}{ MBA (Digital Marketing) } \\
Centurion University, Odisha \\
Semester 1 & Semester 2 \\
Accounting for Business Decisions & Marketing Management \\
Managerial Economics & Financial Management \\
Legal Aspects of Business & Human Resource Management \\
Business Research Methods & Decision Science \\
Organizational Behaviour & Operations \& Supply Chain Management \\
Basics of Marketing & Management Information System \\
Generic Elective Courses & Generic Elective Courses \\
Management Fundamentals & Statistical Software Lab \\
Business Communications Lab & Life Skills Lab \\
MS Excel \& Advanced Excel Lab & Geopolitics \& the World Economic System \\
Selling \& Negotiation Skills Lab & Business Systems \& Procedures \\
Business, Government \& Society & pmputer Aided Personal Productivity Tools Lab \\
Foreign Language - I Lab & Foreign Language - II Lab \\
Enterprise Analysis - Desk Research & Industry Analysis - Desk Research \\
& \\
\hline
\end{tabular}




\begin{tabular}{|c|c|}
\hline Semester 3 & Semester 4 \\
Strategic Management & Managing for Sustainability \\
Enterprise Performance Management & Dissertation \\
Start-up and New Venture Management & Sales and Distribution Management \\
Summer Internship Project (SIP) & Technology in e-Commerce \\
Introduction to Digital Marketing \& e- & Subject Elective Courses \\
Commerce & Social Media Marketing -II \\
Digital Strategies\& Planning & Mobile Marketing \\
Subject Elective Courses & Web Analytics \\
Search Engine Optimization (SEO) & Affiliate Marketing \\
Search Engine Marketing & Online Reputation Management \\
Email Marketing & Brand Planning \& Consumer Insights \\
Social Media Marketing -I & \\
Digital Branding & \\
Content Marketing & \\
AdTech \& MarTech & \\
& \\
\hline
\end{tabular}

The universities are also playing the curricula with Management Science focus and Information Science focus. For example, according to the NIIT University, Rajasthan the core areas and papers include-

- Marketing Management in the Digital Environment

- Consumer Behaviour in the Digital Environment

- Digital Marketing Strategy

- Marketing Channels in the Digital environment

- Technology Management in Digital and Social Media

Few Universities also started the specialization at the last semester while few have started from the beginning of the program. Centurion University, Odisha, for example, started the Digital Marketing focus from the beginning (Refer table: 6) [20].

\section{Findings}

- Information Science is a broad filed of fields includes the areas of information and technology both with a due concentration on social and management issues.

- Information Science also related (and sometimes termed) as Informatics, Information Science and Technology, Information Science, and Computing or Information Systems.

- Information Sciences with its application in the areas of Business, Administration, and Management lead to the concept Business Informatics/ Information Science. Gradually the concepts become full-fledged subject and program in international academic context.

- Business Information Sciences may be treated as broad field and incorporating latest Business and IT related areas viz. Business Informatics, Business IT, Management Information Systems, IT Management, Information Systems (Business Context), Business Intelligence \& Warehousing etc.

- In India the program and even term Business Information Science not yet popular but as far as this study is concerned it is noted that Private Universities are doing well in respect of promoting newer subjects and here new age degrees and subjects viz. Digital Marketing, E-Commerce etc may be considered within this.

- India holds about 800+ universities out of which 279 are private university category and among these 15 universities are offering Masters programs in this field with 18 programs.

- Still, there is no program on Business Information Science; though it may be developed as a full-fledged program or under the ambit of related programs. 


\section{Suggestion}

- Apart from private universities, other Universities in India having Management, Business and Administration related departments and program in their ambit and many of these universities also having Computing/ IT related departments and programs; hence Business Information Science related program may be started as a program/ field or area may also be offered as a program or degree viz. Business Analytics, Business Information Systems, Management Information Science as a Major in Business Information Science (BSc/MSc/BTech/MTech) program.

- Related Computing program viz. Computer Application is available with BCA and MCA degree and both may be offered with broad specializations of Business Information Science as BCA/MCA (Business Information Science). In India, Computing field is also available as Engineering program and thus BTech/ MTech in Business Information Science.

- Industry Collaboration, training program, placement program etc are must for the broad Business Information Science program or its subfields and thus universities need to adopt strategies for such programs.

\section{Conclusion}

Indian Universities are doing well in terms of offering newer programs with different kind of educational models etc. Among the universities in private sectors, new age programs are very much important and valuable. In Information Science segment private universities are doing well and many universities have started different domain based Information Sciences viz. Geo Informatics, Bio Informatics, Health Informatics/ Information Science, Library Information Science etc. As far as the Business segment is concerned not a single universities (from all of its kinds) have started broad Business Information Science (BIS) program. The specialized areas within BIS such as Digital Marketing, Business Intelligence, Business Analytics, Data Analytics though offered in a different level of education in a different type of universities including private one. Though, such specializations may be offered as Major within Business Information Science. Hence the program may be offered as MSc-Business Information Science (Digital Marketing/ Business Analytics/ E-Commerce etc). This model of educational delivery not only enhances the curricula but also will help in jobs in private and public sectors in a country like India!

\section{References}

[1] Agarwal, P. (2007). Higher education in India: Growth, concerns and change agenda. Higher Education Quarterly, 61(2), 197-207.

[2] Brynjolfsson, E., \& Hitt, L. M. (2000). Beyond computation: Information technology, organizational transformation and business performance. Journal of Economic perspectives, 14(4), 23-48.

[3] Clemons, E. K., \& Row, M. C. (1992). Information technology and industrial cooperation: the changing economics of coordination and ownership. Journal of Management Information Systems, 9(2), 9-28.Desai, S., \& Kulkarni, V. (2008). Changing educational inequalities in India in the context of affirmative action. Demography, 45(2), 245-270.

[4] Gereffi, G., Wadhwa, V., Rissing, B., \& Ong, R. (2008). Getting the numbers right: International engineering education in the United States, China, and India. Journal of Engineering Education, 97(1), 13-25.

[5] Kapur, D., \& Mehta, P. B. (2004). Indian higher education reform: From half-baked socialism to half-baked capitalism. Center for international development working paper, 103.

[6] McKnight, L. W., \& Bailey, J. P. (1997). Internet economics: When constituencies collide in cyberspace. IEEE Internet Computing, 1(6), 30-37.

[7] Ma, R. T., Chiu, D. M., Lui, J., Misra, V., \& Rubenstein, D. (2010). Internet Economics: The use of Shapley value for ISP settlement. IEEE/ACM Transactions on Networking (TON), 18(3), 775-787.

[8] Nambissan, G. B., \& Rao, S. (Eds.). (2013). Sociology of education in India: Changing contours and emerging concerns. New Delhi: Oxford University Press.

[9] Paul, P. K., Kumar, A., Poovammal, E., \& Dangwal, K. L. (2014). Information Science: A Potential interdisciplinary field with Historical Perspectives and Future Potentials. Educational Quest, 5(3), 211-215.

[10] Paul, Prantosh and Bhuimali, A. and Aithal, P. S. (2017), Indian Higher Education: With Slant to Information Technology - a Fundamental Overview. International Journal on Recent Researches In Science, Engineering \& Technology, 5(11), 31-50.

[11] Paul, P. K., Aithal, P. S. and Bhuimali, A., (2017). Computing \& Allied Engineering Domain in India with Reference to Private Universities: A Case Study of Bachelors Programs, International Journal on Recent Researches In Science, Engineering \& Technology, 5(11), 51-63. 
[12] Paul, P. K., Bhuimali, A. Aithal, P. S. \& Chattarjee D. (2017). Information Science towards IST: Emerging Interdisciplinary Domain with Expert Definition, Existing and Future Scenario. International Journal on Recent Researches in Science, Engineering \& Technology, 5(10), 45-53.

[13] Paul, P.K., Bhuimali, A. Aithal, P. S. (2018). Role of Economics and Allied Sciences into Information and Computing fields: Emphasizing Economics \& IT Programs - World and Indian Context, IRA-International Journal of Management $\&$ Social Sciences, $10(1), 36-45$.

[14] Sharma, Jagdish (2006). Diaspora: History of and Global Distribution. Encyclopedia of India (vol. 1) edited by Stanley Wolpert, pp. 331-336, Thomson Gale, ISBN 0-684-31350-2.

[15] Sharma, Shalendra D. (2006). Globalization. Encyclopedia of India (vol. 2) edited by Stanley Wolpert, pp. 146-149, Thomson Gale, ISBN 0-684-31351-0.

[16] Singal, N. (2006). Inclusive education in India: International concept, national interpretation. International journal of disability, development and education, 53(3), 351-369.

[17] Tate, D. S., \& Schwartz, C. L. (1993). Increasing the retention of American Indian students in professional programs in higher education. Journal of American Indian Education, 33(1), 21-31.

[18] Tayade, M. C., \& Kulkarni, N. B. (2011). The Interface of technology and medical education in india: current trends and scope. Indian Journal of Basic \& Applied Medical Research, 1(1), 8-12.

[19] Tijerina, K. H., \& Biemer, P. P. (1988). The Dance of Indian Higher Education: One Step forward, Two Steps back. Educational Record, 68(4), 86-91.

Web Sources Used

[20] http://www.inurture.co.in/mba-digital-marketing-and-e-commerce-centurion-university/ (Accessed on 09-01-18). 